\title{
Tussen Brussel en de Polder De Europeanisering van Politiek en Bestuur in Nederland
}

Sebastiaan Princen en Kutsal Yesilkagit

Utrechtse School voor Bestuurs- en Organisatiewetenschap

Universiteit Utrecht

Paper voor de NOB-conferentie van vrijdag 29 oktober 2004

Sessie 1 'Governance in the European Union'

Deze paper presenteert een themanummer over de Europeanisering van politiek en bestuur in Nederland dat begin 2005 in het tijdschrift Beleid en Maatschappij zal verschijnen. In bewerkte vorm zal deze paper dienst doen als inleidend artikel van dat themanummer. De inleiding zal worden gevolgd door bijdragen van Ellen Mastenbroek, Markus Haverland, Ron Holzhacker en Leonard Besselink. 


\section{Inleiding: Europeanisering in Nederland}

Over de invloed van de EU op Nederlands bestuur en beleid wordt veel geschreven en gesproken. Hierbij valt op dat veel stellingen - zowel voor als tegen verdergaande Europese integratie - zwak of helemaal niet zijn onderbouwd. Zo wordt in discussies vaak aangehaald dat $70 \%$ à $80 \%$ van de Nederlandse regelgeving direct of indirect op Europese wetgeving zou zijn gebaseerd - een getal dat bij ons weten niet op systematisch onderzoek is gebaseerd en dat bij dergelijk onderzoek in Denemarken en GrootBrittannië aanzienlijk moest worden genuanceerd (Blom-Hansen en Christensen 2004; Page 1998). Een rondgang door de Volkskrant onder Nederlandse kamerleden leverde eveneens een onthutsend beeld op van hun gebrek aan kennis over de EU (Volkskrant 2003).

In de wetenschappelijke literatuur is de invloed van de EU op nationaal beleid en bestuur bekend komen te staan als 'Europeanisering'. De Europeaniseringsliteratuur probeert op systematische manier te analyseren in hoeverre bestuur en beleid in de lidstaten veranderen onder invloed van Europees bestuur en beleid. Daarmee vormt deze literatuur een aanvulling en correctie op de tot voor kort dominante nadruk op beleidsvorming op Europees niveau. In plaats van te kijken hoe lidstaten Europees beleid beïnvloeden, kijkt de Europeaniseringsliteratuur hoe Europees beleid de lidstaten beïnvloedt.

Het beschikbare Europeaniseringsonderzoek laat zien dat de EU weliswaar invloed heeft op de positie en het functioneren van lidstaten, maar dat deze invloed verschilt per land en per onderwerp. In sommige domeinen blijken bepaalde lidstaten redelijk resistent te zijn tegen Europese wet- en regelgeving - een gegeven dat in de literatuur wordt verklaard met behulp van verschillen in binnenlandse instituties en politieke verhoudingen. Bovendien laat de literatuur zien dat Europeanisering niet synoniem is aan convergentie, ofwel de opheffing van institutionele, politieke en beleidsmatige verschillen tussen landen die lid zijn van de EU (vgl. Knill en Lehmkuhl 2002; Unger en Van Waarden 1995).

In dit themanummer staat de Europeanisering van politiek en bestuur in Nederland centraal. De vraag is in hoeverre en op welke wijze de Nederlandse staat is veranderd onder invloed van Europese integratie. In de vier bijdragen wordt deze vraag beantwoord voor verschillende domeinen van beleid en bestuur in Nederland. In dit inleidende stuk plaatsen we deze bijdragen in het bredere kader van de Europeaniseringsliteratuur en zullen we een poging doen de conclusies met elkaar te verbinden.

\section{Europeanisering in de literatuur}

\subsection{Het begrip Europeanisering}

Europeaniseringsonderzoek heeft zich in het afgelopen decennium mogen verheugen in een toenemende populariteit onder bestuurskundigen en politicologen. De grote inspanningen op dit onderzoeksdomein hebben echter niet alleen geleid tot betere inzichten in wat het proces van Europese integratie nu betekend heeft voor burgers en organisaties binnen verschillende politieke, economische en sociale domeinen op 
internationaal, nationaal en regionale niveaus. Het begrip lijkt met haar eigen populariteit op de loop te zijn gegaan; Europeanisering dreigt de vlag voor iedere lading te worden waarin zich 'iets Europees' bevindt (Vink 2003). Dit is duidelijk te merken aan het feit dat de term de omslagen van vele boeken siert en in de titel van menig wetenschappelijk artikel figureert. Legt men deze titels naast elkaar, dan valt op dat een eenduidige betekenis mist (Olsen 2002). De term 'Europeanisering' dreigt dan ook conceptueel “te ver uitgerekt te worden” en daardoor verloren te gaan voor empirisch onderzoek naar de wel degelijk wezenlijke en substantiële gevolgen van Europese integratie voor de internationale politiek en economie, de lidstaten en haar burgers (Radaelli 2000).

In dit themanummer beperken we ons tot één 'gezicht' van het

Europeaniseringsbegrip, namelijk Europeanisering als een variabele die invloed heeft op de interne politieke, bestuurlijke en institutionele domeinen van nationale lidstaten. Van alle te onderscheiden gezichten van Europeanisering is dit momenteel de meest onderzochte en populaire dimensie (Olsen 2002; Goetz 2001). ${ }^{i}$ Het terugbrengen van het begrip Europeanisering tot de invloed die van Europa op nationale staten uitgaat maakt nog geen einde aan de noodzaak tot verdere specificatie van wat we onder dit begrip verstaan. De Europeanisering van lidstaten omvat in de meest brede zin de beïnvloeding van politiek, bestuur, beleid, leefstijlen, smaken en identiteiten van burgers en groepen binnen de lidstaten van de Europese Unie (Radaelli 2000; Mair 2004). Aanpassing omvat dus zowel culturele als structurele elementen (Vink 2003) zodat we ook binnen dit aandachtsgebied specifiek moeten aangeven waar we ons in dit themanummer op zullen richten.

\subsection{De dimensies van Europeanisering}

In dit themanummer beperken we ons tot de invloed van Europeanisering op de politieke, bestuurlijke en beleidsmatige dimensies van nationale lidstaten. In dit themanummer nemen we de conceptuele driedeling van Börzel en Risse (2003) in beleid (policy), politiek (politics) en instituties (polity) als uitgangspunt. Met de Europeanisering van nationaal beleid worden de invloeden die nationale beleidsterreinen en -programma's ondergaan als gevolg van Europees beleid bedoeld. Onder Europees beleid vallen hoofdzakelijk Europese richtlijnen die door de Raad al dan niet samen met het Europees Parlement en de Commissie op terreinen als handel, interne markt, energie, transport, milieu en arbeidszaken zijn uitgevaardigd (Siedentopf en Ziller 1988; Haverland 2000; Héritier 1999; Knill 2001; Falkner e.a. 2005). Europees beleid omvat naast het formele richtlijneninstrument ook 'zachte' ofwel ook genoemd 'nieuwe' beleidsinstrumenten zoals 'benchmarks', gedragscodes en vrijwillige overeenkomsten (Zito e.a. 2003). Een recent bijvoorbeeld hiervan is het zogenaamde Bologna-akkoord waarin de EU ministers van onderwijs met elkaar afspraken het bachelors-masters systeem in het hoger onderwijs in te voeren.

Europeanisering wordt ook een invloed op politieke processen en structuren op nationaal niveau toegeschreven. Hiermee wordt hoofdzakelijk bedoeld dat de inrichting en het functioneren van Europese besluitvormingsprocessen de wijze waarop nationale politieke actoren zich organiseren en handelen beïnvloeden. Van Schendelen (1998) laat bijvoorbeeld zien dat naarmate besluitvorming op beleidsterreinen en -onderwerpen met een sterke invloed op nationaal niveau meer en meer op het niveau van de EU plaats gaat 
vinden, lobbygroepen zich ook zullen richten op de beïnvloeding van

besluitvormingsprocessen op dit niveaus en zich anders gaan organiseren dan zij deden op nationaal niveau (zie ook Mazey en Richardson 1993). Ook kunnen onder invloed van Europeanisering configuraties van belangenvertegenwoordiging op nationaal niveau veranderen. In dit verband verwacht Falkner (1997) bijvoorbeeld dat op den duur nationale corporatistische configuraties onder invloed van het pluralisme in de Europese belangenvertegenwoordiging zullen veranderen.

Ten slotte betogen Börzel en Risse dat ook nationale macro-institutionele verhoudingen zullen veranderen onder invloed van Europese integratie. Europeaniseringsstudies hebben zich hierbij voornamelijk op de institutionele wisselwerking tussen Europese en nationale besluitvorming geconcentreerd. De meeste aandacht lijkt te zijn uitgegaan naar de aanpassingen die de nationale bureaucratieën hebben ondergaan: de organisatie, cultuur en coördinatie van Europees beleid door de nationale overheden (Page en Wouters 1995; Rometsch en Wessels 1996; Hanf en Soetendorp 1998; Knill 2001; Kassim e.a. 2003; Jordan 2003). Ook zijn stelsels van nationale rechtspraak (Conant 2001) en macro-economische instituties (Dyson 2000) niet onberoerd gelaten. Vanuit een meer omvattend perspectief laten studies vanuit de 'multilevel governance' school zien dat ook de relaties tussen nationale en regionale onderdelen van de federale en gedecentraliseerde staten sterk zijn veranderd onder invloed van het Europese integratieproces (Hooghe en Marks 2001; Börzel 1999).

\subsection{Mechanismen van Europeanisering}

Europeanisering kan op verschillende manieren plaatsvinden. De meest voor de hand liggende manier is door Europese wetgeving en afspraken die de lidstaten direct voorschrijven hoe zij hun beleid dienen aan te passen. Dit gaat vaak verder dan alleen de inhoud van het beleid; in toenemende mate schrijven de jurisprudentie van het Hof van Justitie en Europese wetgeving zelf ook voor hoe de uitvoering van dat beleid moet plaatsvinden (zie bijv. Besselink en Widdershoven 1998: 69-71).

Naast deze 'directe' invloed, kan de EU ook op 'indirecte wijze' invloed hebben op de lidstaten. Zo onderscheiden Knill en Lehmkuhl (2002) naast directe aanpassing aan Europese wetgeving ('institutional compliance') twee vormen van indirecte invloed: 'changing domestic opportunity structures' en 'framing domestic beliefs and expectations'. De eerste vorm van indirecte invloed treedt op wanneer Europees beleid de politieke verhoudingen in een lidstaat beïnvloedt, bijvoorbeeld door bepaalde beleidsopties relatief (minder) aantrekkelijk te maken of door de positie van bepaalde politieke actoren te versterken of te verzwakken. Door, bijvoorbeeld, het vrij verkeer van goederen, diensten en kapitaal tussen landen te bevorderen, kan de EU de positie van actoren die relatief mobiel zijn versterken ten opzichte van actoren die niet zo gemakkelijk de grens over gaan. De diverse bijdragen in Hout en Sie Dhian Ho (1997) richten zich vooral op dit mechanisme: zij analyseren de politieke consequenties binnen Nederland van veranderende economische verhoudingen door internationalisering en Europese integratie. De tweede vorm van indirecte invloed komt tot stand door het verspreiden van ideeën en 'best practices'. Op terreinen waar de EU geen regelgevende bevoegdheden heeft, is dit ondertussen een beproefde strategie geworden. De Open Coördinatiemethode, waarbij vertegenwoordigers van diverse lidstaten elkaars beleid 
kritisch tegen het licht houden, is een goed voorbeeld van zo’n aanpak (zie bijv. Raad voor Maatschappelijke Ontwikkeling 2004).

Voor een goed beeld van Europeanisering is het dus belangrijk verder te kijken dan de formele aanpassing van Nederlandse wetgeving aan Europese wetgeving. Soms zijn deze indirecte invloeden zelfs sterker dan directe invloeden. Zo stelt het Ruimtelijk Planbureau (2004) dat de EU grote invloed heeft op het Nederlandse ruimtelijk beleid, maar dat deze invloed voornamelijk op indirecte wijze verloopt. Het RPB wijst daarbij vooral op de nieuwe bestuurlijke verbindingen die zijn ontstaan door het Europese integratieproces en de gevolgen die de Europese integratie heeft gehad voor het landgebruik in Nederland. In haar onderzoek naar de convergentie van mededingingsbeleid in Nederland, Duitsland en Oostenrijk, beschrijft Drahos (2001) hoe het Europees mededingingsrecht aan de basis heeft gestaan van de Nederlandse Mededingingswet uit 1997, ook al was er geen verplichting voor Nederland om zijn binnenlandse mededingingsbeleid aan te passen aan het Europese model. Volgens Drahos kan dit verklaard worden uit een combinatie van indirecte 'invloedskanalen' via welke het Europees mededingingsbeleid doordrong in Nederland. Enerzijds was het voor beleidsmakers en internationaal opererende bedrijven aantrekkelijk om te streven naar aansluiting bij de Europese regelgeving, anderzijds fungeerde de Europese regelgeving als een model voor de voorstanders van nieuw mededingingsbeleid in Nederland (Ibid.: 238, 382-384).

\subsection{Gradaties van Europeanisering}

Europeanisering kan in verschillende gradaties plaatsvinden. Risse en Börzel (2003) hebben deze gradaties beschreven als drie vormen van aanpassing: 'absorptie', 'accommodatie' en 'transformatie'. ii Bij absorptie wordt de Europese invloed opgenomen in het nationale beleid of nationale instituties zonder dat van wezenlijke aanpassing sprake is. Van accommodatie is sprake wanneer een lidstaat zijn beleid of instituties zo verandert dat ze in overeenstemming zijn met Europees beleid of een Europees model zonder dat de onderliggende kenmerken van het beleid of de instituties worden aangetast. Bij transformatie worden deze onderliggende kenmerken wel aangetast en worden fundamenteel verschillende vormen van beleid of instituties in het leven geroepen.

De vorm van aanpassing verschilt sterk per lidstaat, per beleidsterrein en zelfs per onderwerp. In zijn algemeenheid laat Europeaniseringsonderzoek zien dat nationale instituties en tradities taai zijn en dat zij niet of slechts langzaam veranderen onder invloed van de EU. Dit geldt ook voor Nederland. Zo betoogt Harmsen (1999), in een vergelijkende studie tussen Frankrijk en Nederland, dat de nationale tradities van beleidsvorming en beleidsuitvoering de belangrijkste verklaring vormen voor hoe de beide landen omgaan met Europees beleid. De Rooij (2004) concludeert dat Nederlandse gemeenten zich alleen bezighouden met de EU wanneer zij direct geld ontvangen uit Europese fondsen. Hij stelt dan ook dat de positie van de centrale overheid in Nederland nauwelijks door de Europese integratie wordt bedreigd.

Ook waar wel aanpassingen plaatsvinden, worden zij vaak sterk bepaald door binnenlandse factoren. Zo verklaart Versluis (2003) het verschil in aandacht voor de uitvoering van Europese regelgeving grotendeels uit de politieke aandacht die er binnenlands voor het betreffende onderwerp is. De al eerder genoemde veranderingen in 
het Nederlandse mededingingsbeleid zijn weliswaar geïnspireerd op het Europese model, maar kwamen alleen tot stand door een samenloop met veranderende opvattingen over industriebeleid en marktordening in Nederland zelf (Drahos 2001: 382-384).

Voor een belangrijk deel wordt de mate en wijze van aanpassing aan de EU dus bepaald door binnenlandse politieke verhoudingen. Tegelijkertijd zijn deze verhoudingen zelf niet immuun voor het proces van Europese integratie. Zo betoogt Hennis (1997: 186188) dat veranderingen in het Europese landbouwbeleid in de jaren '90 hebben geleid tot een doorbreking van de traditioneel sterk corporatistische structuur van de sector. Hierdoor kreeg het Ministerie van LNV een centralere rol in het beleidsproces en werd de rol van milieugroeperingen belangrijker.

Daarnaast lijkt binnen het Nederlands openbaar bestuur een zekere centralisatie te hebben plaatsgevonden. Deze centralisatie manifesteert zich op drie manieren. Ten eerste tracht de rijksoverheid bij Europese onderwerpen zijn greep op gemeenten en provincies te vergroten uit angst aansprakelijk te worden gesteld voor verkeerde beleidsuitvoering op decentraal niveau (vgl. Besselink en Widdershoven 1998: 23-24). Ten tweede lijkt de Europese integratie op het nationale niveau de invloed van de regering ten opzichte van het parlement te hebben vergroot, omdat de ministers en hun ambtenaren Nederland vertegenwoordigen op het Europese niveau. Hierdoor hebben zij een directere invloed heeft op Europese wetgeving waardoor zij zich aan verantwoording tegenover het parlement kunnen onttrekken (Princen, te verschijnen; zie ook Del Grosso 2000; Soetendorp en Hanf 1998: 42-43). Bij de omzetting van Europese in Nederlands regelgeving is de rol van het parlement en adviesorganen geleidelijk ook teruggedrongen, waardoor de regering en de afzonderlijke ministeries een sterkere positie hebben gekregen (Besselink en Widdershoven 1998: 13-14; Harmsen 1999: 103). Binnen de regering, ten slotte, is de positie van de Minister-President in de loop der tijd sterker geworden, een ontwikkeling die deels het gevolg lijkt van diens prominente positie op Europees niveau in de Europese Raad (Harmsen 1999: 95-96).

\section{Beperkingen van de literatuur}

Europeaniseringsstudies hebben veel bijgedragen aan de kennis over zowel de invloed van Europa op nationale lidstaten als de mechanismen die verantwoordelijk zijn voor deze beïnvloeding. Er zijn echter nog een tal van empirische en methodologische problemen die verdere aandacht en uitdieping verdienen.

Een van de belangrijkste beperkingen van de Europeaniseringliteratuur is het ontbreken van een coherent conceptueel kader van waaruit processen van Europeanisering kunnen worden bestudeerd. Hoewel in de literatuur onderscheid wordt gemaakt tussen verschillende dimensies, mechanismen en typen Europeanisering, zijn de precieze indelingen niet altijd even duidelijk. Zo worden de begrippen 'policy', 'politics' en 'polity' vaak losjes gebruikt. Een verandering in de organisatorische structuur van een ministerie kan dan als verandering in 'polity' worden gezien, maar met even veel recht als onderdeel van een verandering in 'policy'.

In dit themanummer hebben we dit trachten te ondervangen door deze drie begrippen nader in te vullen. Bij 'policy' kijken we naar veranderingen in wetgeving en beleid; bij 'politics' kijken we naar de relatie tussen regering en parlement; en bij 'polity' richten we ons specifiek op veranderingen in de constitutionele verhoudingen. Hoewel de 
conceptuele onhelderheden hiermee wellicht meer worden omzeild dan inhoudelijk opgelost, menen we op deze manier in ieder geval binnen het themanummer een heldere analyse te kunnen maken van Europeanisering op verschillende 'niveaus' binnen het Nederlands openbaar bestuur.

Een tweede beperking van de literatuur is dat het causaal effect van Europese integratie op nationale veranderingen vaak meer wordt verondersteld dan aangetoond, een probleem dat recent ook binnen de Europeaniseringsliteratuur zelf is onderkend (Goetz 2001; Haverland 2003). Haverland betoogt onder andere dat het causaliteitsprobleem verscholen ligt in de (onzorgvuldige) selectie van cases: veelal worden alleen cases met een evident of potentieel Europees effect geselecteerd en is er te weinig variatie op de onafhankelijke variabele. Het probleem wordt nog pregnanter wanneer studies over de effecten van 'Nieuw Publiek Management' (NPM) op overheidshervormingen, liberalisering van economische sectoren, privatiseringen en dereguleringsoperaties in verschillende OECD landen naast de Europeaniseringsstudies worden gelegd (Peters en Savoie 1998; Christensen en Laegreid 2001): de te verklaren fenomenen van beide domeinen overlappen elkaar grotendeels, waarbij Europeanisten de veranderingen op nationaal niveau graag toeschrijven aan de invloed van Europese besluitvorming en bestuurskundigen de hervormingen vrijwel uitsluitend zien als de effecten van de opkomst van het neo-liberalisme en de NPM ideologie.

Het vaststellen van causaliteit in complexe situaties waar meerdere invloeden tegelijk spelen, blijft een moeilijk methodologisch probleem. Om een causaal verband in ieder geval aannemelijk te maken, wordt in de bijdragen aan dit themanummer expliciet aandacht besteed aan de vraag in hoeverre de geconstateerde veranderingen het gevolg zijn van Europese integratie en in hoeverre van andere factoren.

Een derde beperking is dat het merendeel van de bestaande literatuur zich richt op de invloed van directe harmonisatie van wetgeving vanuit de EU en niet op de indirecte of 'zachte' vormen van beïnvloeding (Zito e.a. 2003). Ook binnen de literatuur over Nederland richt de meeste aandacht zich op Europese wetgeving. Aan de ene kant is veel geschreven over de manier waarop de Nederlandse overheid intern omgaat met zijn standpuntbepaling voor Europese besluitvormingsprocessen (bijv. Harmsen 1999; Schout en Nomden 2000; Soetendorp en Hanf 1998; Van den Bosch 1991). Anderzijds is er ook veel aandacht voor de omzetting en, meer recent, implementatie van Europese wetgeving (Bestuurskunde 1993; Harmsen 1999; Kooiman e.a. 1988; Mastenbroek 2003; Versluis 2003).

Dit vormt ook het duidelijkste en gemakkelijkst te bestuderen voorbeeld van Europeanisering - vanuit de EU worden dan immers direct eisen geformuleerd waaraan nationale wetgeving moet voldoen. Zoals boven betoogd, kan Europeanisering echter ook op indirecte manier plaatsvinden. Deze indirecte kanalen zijn moeilijker te onderzoeken, omdat het lastig is Europese invloeden te onderscheiden van andere invloeden.

Tegelijkertijd zijn deze indirecte kanalen potentieel van groot belang, met name op de diepere niveaus van bestuur en politiek in een land. In de bijdragen aan het themanummer komen dan ook beide vormen van Europeanisering aan de orde: direct door Europese harmonisatie en indirect door veranderingen in de manier waarop het politieke en bestuurlijke spel wordt gespeeld in een land.

Als laatste beperking richten Europeaniseringsstudies zich over het algemeen op een van de drie dimensies van Europeanisering en isoleren zij daardoor de beleids-, 
politieke en institutionele dimensies. Bovendien wordt in theoretische zin wel erkend dat Europeanisering ook betrekking heeft op instituties en politiek, maar richten de meeste empirische studies zich op de Europeanisering van nationaal beleid. Over de Europeanisering van nationale instituties en politiek is een stuk minder bekend, zeker waar het niet gaat om organisatorische aanpassingen binnen de rijksoverheid maar om bredere politieke en constitutionele verhoudingen.

Een van de meest uitgesproken kritieken op deze tekortkoming binnen de Europeaniseringsstudies is afkomstig van Anderson (2002: 798)

Where polity as a whole, defined loosely as a territorially bounded constellation of institutions, has surfaced consistently in the published literature, as in studies premised on the notion of institutional fit, it serves as a macro-structural context within which one looks for Europeanization effects on policy outcomes or processes, with the aim of discovering the implications of their differing institutional logics ... [However] the various institutions that together form the democratic polity operate not in splendid isolation from one another, but in ways that are inherently interdependent.

Verschillende studies van individuele lidstaten en studies van niet-lidstaten die effecten van Europeanisering hebben ondergaan ondersteunen zijn kritiek (Ladrech 1994; Kerremans en Beyers 1998; Cole en Drake 2000; Falkner 2001; Sciarini e.a. 2004). Echter, deze studies gaan niet verder dan het onderzoeken van Europeanisering op andere dan de beleidsdimensie. Ofschoon zeer systematisch en uitputtend, blijft ook Andersons empirisch onderzoek beperkt tot de mate waarin de polity is veranderd.

In dit themanummer willen we juist ook onderzoeken in hoeverre er wederzijdse beïnvloeding plaatsvindt tussen de verschillende dimensies: leiden aanpassingen op beleidsniveau tot veranderingen in de wijze waarop belangenvertegenwoordiging plaatsvindt?; resulteren substantiële aanpassingen op deze dimensies tot substantiële aanpassingen op het niveau van de constitutionele verhoudingen?; en in welke richting verloopt de invloed dan: van beleid naar politiek en constitutie of omgekeerd?

\section{Bijdragen in en conclusies van dit nummer}

\subsection{De bijdragen}

In het eerste artikel analyseert Mastenbroek de omzetting van richtlijnen in Nederland. Zij constateert dat de achterstanden en tijdsoverschrijdingen bij de omzetting een hardnekkig probleem zijn. In haar artikel confronteert ze twee mogelijke verklaringen hiervoor: enerzijds politieke onwil, anderzijds politiek-bestuurlijke onmacht. Uit haar analyse blijkt dat politieke onwil in Nederland een geringe rol speelt en dat de meeste vertragingen het gevolg zijn politiek-bestuurlijke onmacht. Deze onmacht is volgens haar weer een gevolg van de betrekkelijke onverschilligheid waarmee omzetting in politiek Den Haag is bezien: niet onwil, maar onverschilligheid lijkt daarmee de sleutel tot het verklaren van late omzetting.

Mastenbroeks artikel toont ook de verschuivingen in de verhoudingen tussen regering en parlement. Hoewel de cijfers daar geen aanleiding toe geven, wordt de 
oorzaak van verlate omzetting vaak gezocht in (lange) parlementaire procedures. Omzetting kan zo gebruikt worden als argument om de rol van het parlement terug te dringen.

Haverland kijkt vervolgens naar de inhoud van beleidsverandering onder invloed van de EU. Hij vergelijkt hierbij twee beleidsonderwerpen, waarop de Europese invloed via verschillende mechanismen gestalte krijgt. Bij het eerste onderwerp, verpakkingsafvalbeleid, was sprake van directe invloed vanuit Europese wetgeving die in Nederland moest worden omgezet. Bij het tweede onderwerp, spoorbeleid, was er nauwelijks Europese regelgeving en verliep de invloed via indirecte mechanismen van Europeanisering. Opmerkelijk is dat het Europese beleid meer invloed bleek te hebben bij de indirecte invloed (in het spoorbeleid) dan bij de directe invloed (bij het verpakkingsafvalbeleid). Haverland concludeert dan ook dat binnenlandse politieke factoren een belangrijkere rol spelen dan de vorm van beleid op Europees niveau.

Verder laat Haverland zien dat de Europese regelgeving op het gebied van verpakkingsafval weliswaar geen directe invloed had op de inhoud van het Nederlands beleid, maar wel op de structuur van het beleidsnetwerk rond het onderwerp. Aanvankelijk bestond dit uit het ministerie van VROM en een klein aantal belangenorganisaties uit het bedrijfsleven. Door de Europese regelgeving werd dit netwerk opengebroken, waardoor ook ruimte ontstond voor het Ministerie van Economische Zaken en een breder scala aan partijen uit het bedrijfsleven. Desalniettemin concludeert Haverland dat het beleidsnetwerk in essentie corporatistisch van karakter bleef, hetgeen hij als bewijs ziet voor de veerkracht van de bestaande Nederlandse verhoudingen op dit gebied.

Holzhacker richt zich op de relaties tussen parlement en regering. Hij kijkt naar interacties tussen partijen onderling en tussen partijen en ministers bij de behandeling van Europese beleidsdossiers. Holzhacker betoogt dat de ruimte van de Tweede Kamer om invloed uit te oefenen relatief gering is wanneer Europese wetgeving moet worden omgezet. De grootste invloed kan dan ook worden uitgeoefend in de aanloop naar een Europees besluit, maar uitgerekend in deze fase heeft de Kamer weinig bevoegdheden. In het algemeen vertonen de relaties tussen partijen dezelfde dynamiek als bij binnenlandse onderwerpen, maar op sommige punten hebben de coalitiepartijen meer ruimte dan zij bij binnenlandse onderwerpen hebben. Dit komt doordat veel Europese kwesties niet in het regeerakkoord zijn vastgelegd en doordat de adviesrol die de Tweede Kamer bij veel Europese dossiers heeft meer ruimte laat om kritiek uit te oefenen.

Besselink, ten slotte, kijkt naar de invloed van de Europese integratie op constitutionele verhoudingen. Hij constateert in deze verhoudingen een belangrijke verschuiving, waarbij de rol van de uitvoerende en de rechterlijke macht is versterkt ten koste van die van het parlement. Opvallender vindt Besselink het ontbreken van een debat over de rol van Europees recht in de Nederlandse constitutionele orde en het ontbreken van aanpassingen aan de grondwet zelf. Hij verklaart dit enerzijds uit de openheid voor de internationale rechtsorde die de Nederlandse constitutie kenmerkt en anderzijds uit het feit dat veel constitutionele praktijken niet formeel in de grondwet zijn vastgelegd. Hierdoor heeft de Nederlandse constitutie veeleer een 'materieel' dan een 'formeel' karakter en vinden verschuivingen eerder plaats binnen praktijken dan binnen formele (grond)wetsteksten. 


\subsection{Conclusies}

Wat leert ons dit nu over de Europeanisering van Nederland? Om te beginnen laten de bijdragen zien dat de EU op verschillende terreinen en op verschillende manieren invloed heeft op het Nederlands openbaar bestuur. Van transformaties, in de zin van de verschillende gradaties van Europeanisering, lijkt echter geen sprake. Op sommige gebieden zal eerder van accommodatie sprake zijn, terwijl de beschreven Europeaniseringsprocessen vaak ook kenmerken van absorptie vertonen. In de woorden van Harmsen (1999: 86) lijkt minder sprake van 'a process of national adaptation to European norms' dan van 'one of European norms being adapted to, or at least within, national contexts'.

De bijdragen laten ook zien dat indirecte mechanismen van Europeanisering op veel gebieden een belangrijke rol spelen. De invloed op de politieke en constitutionele verhoudingen, die in de artikelen van Holzhacker en Besselink centraal staan, verloopt bijna volledig via indirecte kanalen omdat de EU op deze gebieden weinig tot geen regelgevende bevoegdheden heeft. Ook op het niveau van beleid zijn indirecte mechanismen belangrijk, zoals Haverland laat zien.

De invloed van de EU lijkt vooralsnog groter op de beleidsdimensie dan op de politieke en constitutionele dimensies van Europeanisering. Desondanks laten de bijdragen van Holzhacker en Besselink zien dat ook deze verhoudingen zijn verschoven door het Europees integratieproces.

De richting van invloed tussen de drie dimensies van Europeanisering ligt niet vast. Enerzijds verloopt de invloed van Europese integratie vanuit het beleid naar politieke en constitutionele verhoudingen. Door specifieke vormen van beleid en specifieke beleidsinstrumenten te kiezen, vinden 'en passant' verschuivingen plaats in beleidsnetwerken en de manieren waarop politieke actoren met elkaar omgaan.

Anderzijds grijpt de Europese integratie ook direct in op politieke en constitutionele verhoudingen. Dit gebeurt niet doordat Europese regelgeving direct voorschrijft hoe binnenlandse verhoudingen eruit zouden moeten zien, maar doordat Europese besluitvormingsprocessen meer kansen bieden voor sommige actoren dan voor andere. Dit blijkt met name uit de bijdragen van Holzhacker en Besselink, die beiden aangeven hoe de rol van de regering relatief sterker is geworden door het Europees integratieproces. Dit kan, op zijn beurt, weer invloed hebben op de inhoud van beleid.

Zowel het grote belang van indirecte invloedsmechanismen als de invloed op de diverse Europeaniseringsdimensies is begrijpelijk vanuit de manier waarop binnenlandspolitieke actoren omgaan met en gebruik maken van de kansen en beperkingen die de EU oplevert. Haverland laat expliciet zien dat actoren op verschillende beleidsterreinen actief gebruik maken van Europees beleid om hun eigen agenda's te bevorderen. Ook de analyses in de andere drie bijdragen laten zien dat Europese debatten inzet worden van een binnenlandspolitieke strijd waarbij actoren proberen hun eigen positie te versterken met behulp van de EU.

Voor een goed begrip van Europeaniseringsprocessen is het daarom belangrijk de EU niet te zien als een actor die doelbewust invloed uitoefent op de lidstaten. De EU is eerder een arena (of verzameling arena's) waarbinnen andere actoren, zowel vanuit de lidstaten als op Europees niveau, proberen hun politieke doelstellingen te verwezenlijken. 
Omdat de toegang tot de Europese arena's anders werkt dan die tot binnenlandse arena's leidt dit tot verschuivingen in beleid en in de binnenlandse arena's zelf.

Dit perspectief biedt ook een oplossing voor het probleem van causaliteit in Europeanisering. De bijdragen laten elk zien dat de invloed vanuit de EU sterk verweven is met andere ontwikkelingen en factoren. Hierdoor is het niet goed mogelijk de invloed van de EU te isoleren. Wanneer de EU als arena wordt gezien, wordt dat een stuk minder problematisch: de invloed van 'de EU' is dan immers afhankelijk van de manier waarop politieke actoren gebruik maken van deze arena en de ideeën en belangen die zij daarin meebrengen. Wanneer ideeen en belangen binnen lidstaten veranderen, heeft dit grote invloed op de uitkomsten van Europese besluitvorming, terwijl actoren in de lidstaten de EU zullen gebruiken om hun politieke ideeën te verwezenlijken. De EU is dan veeleer een katalysator dan een zelf handelende actor - maar een katalysator kan grote invloed hebben op de uitkomsten van een proces.

De tegenstelling tussen Europeanisering en New Public Management als alternatieve verklaringen voor beleidsveranderingen, die wij eerder beschreven, is hier mogelijk een goed voorbeeld van. De opkomst van NPM en de inhoud van Europees beleid kunnen niet los van elkaar worden gezien: door de opkomst van NPM veranderde de politieke agenda binnen de EU terwijl de EU als arena, met zijn nadruk of marktintegratie en marktwerking, goede mogelijkheden bood om de NPM-agenda te verbreiden. Het is als met voetbal: de EU stelt de spelregels vast, maar de strategieën en capaciteiten van de spelers bepalen de einduitslag. 


\section{Literatuur}

Anderson, Jeffrey (2002). Europeanization and the Transformation of the Democratic Polity, Journal of Common Market Studies, 40 (5): 793-822.

Besselink, L.F.M. en R.J.G.M. Widdershoven (1998) Juridische Gevolgen van Europese Integratie voor het Nationaal Beleid, Preadvies voor de Raad voor het Openbaar Bestuur, september 1998.

Bestuurskunde (1993) 'Uitvoering van EG-Beleid in Nederland', Themanummer van het tijdschrift Bestuurskunde, 2 (4): 158 e.v.

Blom-Hansen, J. en J.G. Christensen (2004). Den europæiske forbindelse. Aarhus: Magtudredningen.

Börzel, Tanja (1999). Towards Convergence in Europe? Institutional Adaptation to Europeanisation in Germany and Spain. Journal of Common Market Studies, 37 (4): 573596.

Börzel, Tanja en Thomas Risse (2003). Conceptualizing the Domestic Impact of Europe. In: Kevin Featherstone en Claudio Radaelli (eds.) (2003). The Politics of Europeanization.

Oxford: Oxford University Press, pp. 57-80.

Bosch, Jan M.M. van den (1991) Dutch EC Policy Making - A Model-Guided Approach to Coordination and Negotiation, Proefschrift, Universiteit Utrecht.

Conant, Lisa J (2001). Europeanization and the Courts: Variable Patterns of Adaptation among National Judiciaries. In: Maria Green Cowles, James A. Caporaso en Thomas Risse (eds.), Europeanization and Domestic Change. Ithaca, NY: Cornell University Press.

Caporaso, James A, en Joseph Jupille. (2001). The Europeanization of Social Policy and Domestic Political Change. In: Maria Green Cowles, James A. Caporaso en Thomas Risse (eds.), Europeanization and Domestic Change. Ithaca, NY: Cornell University Press.

Christensen, Tom en Per Laegreid (eds.) (2001). New Public Management: The Transformation of Ideas and Practice. Aldershot: Ashgate.

Cole, Alistair en Helen Drake (2000). The Europeanization of the French Polity:

Continuity, Change and Adaptation. Journal of European Public Policy, 7 (1): 26-43.

Del Grosso, N.Y. (2000) Parlement en Europese Integratie, Deventer: Kluwer.

Drahos, Michaela (2001) Convergence of Competition Laws and Policies in the European Community. Germany, Austria, and the Netherlands, Den Haag: Kluwer Law International.

Dyson, Kenneth (2000). EMU as Europeanization: Convergence, Diversity and Contingency. Journal of Common Market Studies, 38 (4): 645-666.

Falkner, Gerda (1997). Corporatist Governance and Europeanisation: No Future in the Multi-Level Game? European Integration Online Papers 1 (11), consulted in September 2003.

Falkner, Gerda (2001). The Europeanisation of Austria: Misfit, Adaptation and Controversies, European Integration online Papers, 5 (13).

Falkner, Gerda, Oliver Treib, Mirian Hartlapp en Simone Leiber (2005), Complying with Europe? The Impact of EU Minimum Harmonisation and Soft Law in the Member States, Cambridge: Cambridge University Press (forthcoming)

Goetz, Klaus H. (2001). European Integration and National Executives: A Cause in Search of an Effect? In: Klaus H. Goetz en Simon Hix (eds.). Europeanized Politics? European Integration and National Political Systems. London: Cass Publishers, pp. 211-231. 
Hanf, Kenneth en Ben Soetendorp (eds.) (1998). Adapting to European Integration: Small States and the Euroepan Union. London en New York: Longman.

Harmsen, Robert (1999) 'The Europeanization of National Administrations: A Comparative Study of France and the Netherlands', Governance, 12 (1): 81-113.

Haverland, Markus (2000). National Adaptation to European Integration: The Importance of Institutional Veto Points. Journal of Public Policy, 20 (1): 83-103.

Haverland, Markus (2003). Methodological Issues in Europeanisation Research: The "No Variation” Problem. Paper prepared for ECPR Conference Marburg, 18-21 September 2003.

Hennis, Marjoleine (1997) 'Nieuwe Actoren en Instituties in het Landbouwbeleid', in: Hout, Wil en Monika Sie Dhian Ho (red.) Aanpassing onder Druk? Nederland en de Gevolgen van de Internationalisering, Assen: Van Gorcum, pp. 179-191.

Héritier, Adrienne (1999). Policy-making and Diversity in Europe: Escaping Deadlock. Cambridge: Cambridge University Press.

Hix, Simon en Klaus Goetz (2000). Introduction: European Integration and National Political Systems, West European Politics, 23 (4): 1-26.

Hooghe, Liesbet en Gary Marks (2001). Multi-Level Governance and European Integration. Boston: Rowman \& Littlefield Publishers.

Hout, Wil en Monika Sie Dhian Ho (red.) (1997) Aanpassing onder Druk? Nederland en de Gevolgen van de Internationalisering, Assen: Van Gorcum.

Jordan, Andrew (2003). The Europeanization of National Government and Policy: A

Departmental Perspective, British Journal of Political Science, 33 (2): 261-282.

Kassim, Hussein, B. Guy Peters en Vincent Wright (eds.) (2003). The National Coordination of EU Policy. Oxford: Oxford University Press.

Kerremans, Bart en Jan Beyers (1998). Belgium: The Dilemma between Cohesion and Autonomy. In: Kenneth Hanf en Ben Soetendorp (eds.), Adapting to European Integration: Small States and the Euroepan Union. London en New York: Longman, pp. 14-51.

Kersbergen, Kees van, Bertjan Verbeek en Anton Hemerijck (1997) 'Gefilterde Druk: De Rol van Nationale Instituties’, in: Hout, Wil en Monika Sie Dhian Ho (red.) Aanpassing onder Druk? Nederland en de Gevolgen van de Internationalisering, Assen: Van Gorcum, pp. 45-60.

Knill, Christoph (2001). The Europeanisation of National Administrations: Patterns of Institutional Change and Persistence, Cambridge: Cambridge University Press.

Knill, Christoph en Dirk Lehmkuhl (2002) 'The National Impact of EU Regulatory Policy: Three Europeanization Mechanisms', European Journal of Political Research, Vol. 41, No. 2, pp. 255-280.

Kooiman, J., P. Yntema en L. Lintsen (1988) 'The Netherlands', in: H. Siedentopf en J. Ziller (eds) Making European Policies Work. The Implementation of Community Legislation in the Member States, Vol. II: National Reports, London: Sage, pp. 573-636.

Ladrech, Robert (1994). Europeanization of Domestic Politics and Institutions: The Case of France. Journal of Common Market Studies, 32 (1): 69-88.

Mair, Peter (2004), 'The Europeanisation Dimension', Review Section, Journal of European Public Policy, 11 (2): 337-348.

Mastenbroek, Ellen (2003) 'Surviving the Deadline. The Transposition of EU Directives in the Netherlands', European Union Politics, Vol. 4, No. 4, 
Mazey, Sonia en Jeremy Richardson (eds.) (1993). Lobbying in the European Community. Oxford: Oxford University Press.

Olsen, Johan P. (2002). The many Faces of Europanization. Journal of Common Market

Studies, 40 (5): 921-952.

Page, Edward C. (1998) 'The Impact of European Legislation on British Public Policy

Making: A Research Note', Public Administration, 76: 803-809.

Page, Edward C en Linda Wouters (1995). The Europeanization of National Bureaucracies?

In: Jon Pierre (ed.). Bureaucracy in the Modern State: Problems of Theory and Method.

Tuscaloosa: University of Alabama Press, pp. 185-204.

Peters, B. Guy en Donald J. Savoie (eds.) (1998). Taking Stock: Assessing Public Sector Reforms. Canadian Centre for Management Development. Montreal: McGill-Queen's University Press

Peterson, John (2001). The Choice for EU Theorists: Establishing a Common Framework for Analysis. European Journal of Politics, 39: 289-318.

Princen, Sebastiaan (te verschijnen) 'Europa als Bliksemafleider? De Invloed van de EU op Verantwoordingsregimes in Nederland', in: Wieger Bakker en Kutsal Yesilkagit (red.) Publieke Verantwoording, Jaarboek Beleid en Maatschappij 2004.

Radaelli, Claudio M. (2000). Whither Europeanization? Concept Stretching and Substantive Change. European Integration online Papers, 4, nr. 8.

Raad voor Maatschappelijke Ontwikkeling (2004) Europa als Sociale Ruimte. Open Coordinatie van Sociaal Beleid in de Europese Unie, RMO Advies 28

Rometsch, Dietrich en Wolfgang Wessels (eds.) (1996). The European Union and the Member States: Towards Institutional Fusion? Manchester: Manchester University Press. Rooij, Rob de (2004) “"Den Haag” onder Druk? Over de Relatie tussen de EU, Gemeenten en Provincies’, Bestuurskunde, 13 (6): 279-287.

Ruimtelijk Planbureau (2004) Unseen Europe. A Survey of EU Politics and Its Impact on Spatial Development in the Netherlands (auteurs: N. van Ravesteyn en D. Evers), Rotterdam: NAi Publishers.

Schendelen, M.P.C.M. van (ed.) (1998) National Public and Private EC Lobbying. Aldershot: Ashgate.

Schout, Adriaan en Koen Nomden (2000) 'De Europeanisering van het Nederlandse Openbaar Bestuur, Bestuurswetenschappen, 54 (5): 336-354.

Sciarini, Pascal, Alex Fisher en Sarah Nicolet (2004), 'How Europe Hits Home: Evidence from the Swiss Case', Journal of European Public Policy, 11 (3): 353 - 378.

Siedentopf, Heinrich en Jacques Ziller (eds.) (1988), Making European Policies Work:

The Implementation of Community Legislation in the Member States, Vols. 1 and 2,

Bruxelles: Bruylant - Sage Publications.

Soetendorp, Ben en Kenneth Hanf (1998) 'The Netherlands: Growing Doubts of a Loyal Member', in: K. Hanf en B. Soetendorp (eds) Adapting to European Integration. Small States and the European Union, London en New York: Longman, pp. 36-51.

Unger, Brigitte en Frans van Waarden (1995) 'Introduction: An Interdisciplinary Approach to Convergence', in: B. Unger en F. van Waarden (red.), Convergence or Diversity? Internationalization and Economic Policy Response, Aldershot etc.: Avebury, pp. 1-35.

Versluis, Esther (2003) Enforcement Matters: Enforcement and Compliance of European Directives in four Member States, Delft: Eburon. 
Vink, Maarten (2003), 'What is Europeanisation? And other questions on a new research agenda', European Political Science 3, 1 (autumn 2003): 63-74.

Volkskrant (2003) Een Eiland in de EU? 'Vlieland Misschien', 6 december 2003, voorpagina.

Zito, Anthony R., Claudio M. Radaelli en Andrew Jordan (2003). Introduction to the Symposium on 'New' Policy Instruments in the European Union. Public Administration, 81 (3): 509-511. 


\section{Eindnoten}

${ }^{\text {i }}$ De andere 'gezichten’ zijn de volgende (zie Olsen 2002): Europeanisering als geografisch concept waarin de uitbreiding van de grenzen van Europa centraal staan; de verdergaande ontwikkeling van supranationale instellingen; de verspreiding van levensstijlen, identiteiten, vormen van economische productie en politieke principes; en tot slot het door middel van politieke unificatie ontstaan van een (unieke) internationale politieke orde in Europa.

${ }^{\text {ii }}$ In de literatuur worden ook andere indelingen voorgesteld. Zo onderscheiden Van Kersbergen, Verbeek en Hemerijck (1997: 50) vier niveaus van verandering, die echter specifiek gericht zijn op veranderingen in beleid en instituties die nauw met beleid zijn verbonden. Daarom is deze indeling minder geschikt om veranderingen in politieke verhoudingen en meer fundamentele instituties te duiden. 